\title{
PENGARUH PEMBERIAN LAYANAN PESAN SINGKAT PENGINGAT TERHADAP KEPATUHAN DAN EFEKTIVITAS PENGOBATAN PASIEN HIPERTENSI DI PUSKESMAS KECAMATAN SUMBANG BANYUMAS
}

\author{
THE EFFECT OF GIVING SHORT MESSAGE SERVICE \\ REMINDER ON ADHERENCE AND THE EFFECTIVENESS OF \\ TREATMEN ON PATIENTS WITH HYPERTENSION IN \\ DISTRICT HEALTH CENTER SUMBANG BANYUMAS
}

\author{
Nur'aeni, Anjar Mahardian K, Githa Fungie G \\ Fakultas Farmasi Universitas Muhammadiyah Purwokerto \\ Email : nuraeni0034@gmail.com
}

\begin{abstract}
ABSTRAK
Problem terapi hipertensi diantaranya ketidakpatuhan pasien terhadap terapi non farmakologi dan farmakologi . Ketidakpatuhan pengobatan hipertensi disebabkan oleh berbagai faktor antara lain pengetahuan dan komunikasi pasien dengan tenaga kesehatan. Penelitian Alfian (2014) menyatakan bahwa pemberian layanan pesan singkat pengingat dapat meningkatkan kepatuhan minum obat pasien hipertensi yang diukur dengan parameter kuesioner Morisky Medication

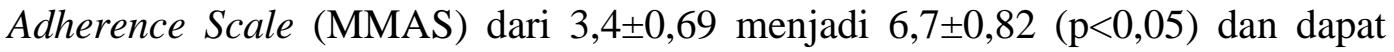
menurunkan tekanan darah pasien hipertensi dengan rata-rata sistolik 17,92 $\pm 12,20$ $\mathrm{mmHg}$ dan rata-rata diastolik $9,17 \pm 8,9 \mathrm{mmHg}(\mathrm{p}<0,05)$. Tujuan penelitian ini adalah mengetahui pengaruh pemberian layanan pesan singkat pengingat terhadap kepatuhan dan efektivitas pengobatan pasien hipertensi di Puskesmas Kecamatan Sumbang Banyumas. Penelitian dilakukan dengan rancangan analitik crosssectional dengan pengambilan data secara prospektif pasien hipertensi selama bulan Januari-Februari 2016. Teknik pengambilan sampel secara purposive sampling. Subyek yang memenuhi kriteria inklusi dan eksklusi sebanyak 75 responden. Pengumpulan data dilakukan dengan melihat nilai Medication Possession Ratio (MPR) dan data tekanan darah dari rekam medik. Hasil menunjukan bahwa pemberian layanan pesan singkat pengingat tidak berpengaruh terhadap kepatuhan dan efektivitas pengobatan pasien hipertensi dimana kepatuhan $p$ value uji chi-square $0,102(\mathrm{P}>0,05)$ dan efektivitas $p$ value uji chisquare $=0,899(\mathrm{P}>0,05)$. Berdasarkan hasil penelitian dapat disimpulkan bahwa pemberian layanan pesan singkat pengingat tidak berpengaruh terhadap kepatuhan dan efektivitas pengobatan pasien hipertensi di Puskesmas Kecamatan Sumbang Banyumas.
\end{abstract}

Kata kunci: Hipertensi, Layanan pesan singkat pengingat, Kepatuhan, MPR, Efektivitas pengobatan, Puskesmas. 


\begin{abstract}
Problem of hypertension therapy includes patientsadherenceon nonpharmacological therapy and pharmacological therapy. Adherence treatment of hypertension caused by various factor including the patient's knowledge and communication with medical personnel. In Alfian's research (2014) stated that giving short message service reminder can increase medication adherence in hypertensive patients as measured by questionnaires parameter Morisky Medication Adherence Scale (MMAS) from $3.4 \pm 0.69$ to $6.7 \pm 0.82(P<0.05$ ) and can lower blood pressure in hypertensive patients with average sistolic 17.,92 $\pm 12.20 \mathrm{mmHg}$ and average diastolic $9.17 \pm 8.9 \mathrm{mmHg}(P<0.05)$. The purpose of this research was to determine the effect of giving short message service reminder on adherence and the effectiveness of treatment on patients with hypertensive in community health center (Puskesmas) Sumbang, Banyumas. This research was conducted with a cross - sectional analytical design with prospective data collection of hypertensive patients. The sampling technique was purposive sampling. Subject who meet the inclusion and exclusion criteria were 75 respondents. The data collection doing by looking at the value of Medication Possesion Ratio (MPR) and data of blood pressure from medical record. Result showed that giving short message service reminder has no effect on adherenceP value of chi square test $=0.102(P>0.05)$ and effectiveness $P$ value of chi square test $=0.899(P>0.05)$. Based on the result of this research concluded that giving short message service reminder no effect on adherence and effectiveness of treatment on patients with hypertension in district health center (Puskesmas) Sumbang, Banyumas.
\end{abstract}

Keywords: Hypertension, short message service reminder, adherence, Medication Possesion Ratio (MPR), the effectiveness of treatment, community health center (Puskesmas).

\title{
PENDAHULUAN
}

Menurut World Health Organization (WHO), pada tahun 2013 setiap tahunnya sekitar 17 juta orang di dunia meninggal akibat penyakit kardiovaskular dan 9,4 juta kematian diantaranya akibat komplikasi hipertensi. Penelitian Riset Kesehatan Dasar (RISKESDAS) tahun 2013 menunjukkan bahwa prevalensi hipertensi pada umur $\geq 18$ tahun di Indonesia sebesar 26,5\%. Provinsi Bangka Belitung mempunyai prevalensi tertinggi di Indonesia yaitu 30,9\%, diikuti Kalimantan Selatan 30,8\%, Kalimantan Timur 29,6\% dan Jawa Barat 29,4\%, sedangkan Jawa Tengah menjadi peringkat ke 11 yaitu sebesar 26,4\%. Data dari Dinas kesehatan Banyumas tahun 2014 penderita hipertensi di Puskesmas 
Kabupaten Banyumas 6,398 pasien, dimana pasien terbanyak terdapat di Puskesmas Kecamatan Sumbang sebesar 896 pasien.

Problem terapi hipertensi diantaranya ketidakpatuhan pasien terhadap terapi non farmakologi dan farmakologi (Rina et al., 2015). Ketidakpatuhan pengobatan hipertensi disebabkan oleh berbagai faktor antara lain pengetahuan dan komunikasi pasien dengan tenaga kesehatan (Rina et al., 2015). Berdasarkan penelitian Mazzaglia pada tahun 2009 ketidakpatuhan pasien hipertensi dalam menjalankan terapi hipertensi mencapai 20-80\% pasien (Febiyanti, 2012). Kepatuhan merupakan faktor penentu keberhasilan terapi, karena kepatuhan dan pemahaman yang baik dalam menjalankan terapi dapat mempengaruhi keberhasilan terapi hipertensi dan secara bertahap mencegah terjadinya komplikasi (Febiyanti, 2012).

Dalam penelitian Alfian (2014) menyatakan bahwa pemberian layanan pesan singkat pengingat dapat meningkatkan kepatuhan minum obat pasien hipertensi yang diukur dengan parameter kuesioner Morisky Medication

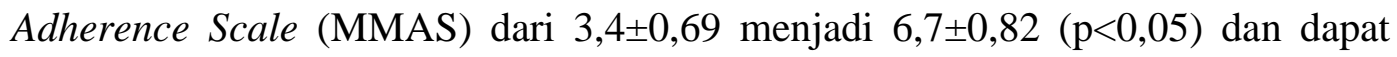
menurunkan tekanan darah pasien hipertensi dengan rata-rata sistolik 17,92 $\pm 12,20$ $\mathrm{mmHg}$ dan rata-rata diastolik $9,17 \pm 8,9 \mathrm{mmHg}(\mathrm{p}<0,05)$, berdasarkan penelitian tersebut peneliti ingin melakukan penelitian pengaruh pemberian layanan pesan singkat pengingat terhadap kepatuhan yang diukur dengan nilai Medication Possession Ratio (MPR), dan efektivitas pengobatan pasien hipertensi di Puskesmas Kabupaten Banyumas.

\section{METODE PENELITIAN}

Penelitian ini dilaksanakan secara analitik cross-sectional. Penelitian analitik karena penelitian ini menjelaskan adanya hubungan sebab akibat yaitu antara pemberian layanan pesan singkat pengingat terhadap kepatuhan dan efektivitas pengobatan pasien hipertensi, Pengambilan data secara prospektif selama bulan Januari-Februari 2016. Teknik pengambilan sampel secara purposive sampling. Subyek yang memenuhi kriteria inklusi dan eksklusi sebanyak 75 responden. Kriteria inklusi dalam penelitian ini adalah pasien pria 
dan wanita usia 18-60 tahun yang didiagnosa hipertensi tanpa penyakit penyerta kronis seperti diabetes mellitus, gagal ginjal, gagal jantung dan lainnya oleh tenaga kesehatan di Puskesmas kecamatan Sumbang, pasien hipertensi yang mendapat terapi obat hipertensi dan mendapatkan pelayanan kesehatan di Puskesmas kecamatan Sumbang pada periode penelitian, pasien yang memiliki HP dan mampu menggunakan layanan pesan singkat, pasien bersedia menjadi responden yang dibuktikan dengan informed consent. Kriteria ekslusinya adalah pasien hipertensi yang mengalami gangguan pendengaran, gangguan penglihatan, kehamilan, dan buta aksara, pasien yang meninggal dunia saat penelitian berlangsung, pasien tenaga medis. Pengumpulan data dilakukan dengan melihat nilai Medication Possession Ratio (MPR), MPR merupakan salah satu metode untuk mengukur kepatuhan secara objektif dan mudah untuk mengumpulkan data. Menurut Robertson et al (2008) MPR adalah rasio jumlah hari mendapatkan obat dibagi jumlah hari yang mendapat obat pada peresepan terakhir dalam persen. Penelitian Suhadi (2010) MPR dihitung dengan rumus modifikasi Robertson et al (2008) yaitu rasio jumlah hari pasien mendapat obat sampai resep terakhir dengan jumlah total hari seharusnya mendapat obat sampai resep terakhir (peresepan terakhir digunakan untuk penentuan batas hari observasi) dan data tekanan darah dari rekam medik, tekanan darah yang diambil yaitu tekanan darah saat pemeriksaan terakhir waktu penelitian. Pasien mendapatkan intervensi layanan pesan singkat pengingat 3 hari sekali selama 1 bulan.

Data yang diperoleh dianalisis dengan SPSS, data diuji normalitas dan untuk mengetahui apakah ada pengaruh atau tidak dilakukan uji chi-square nilai $\mathrm{P}<0,05$ dianggap secara statistika signifikan.

Penelitian ini dilakukan sesuai dengan prosedur yang telah disetujui oleh tim penelaah dari Komisi Etik Penelitian Kedokteran FK UnSoed dan telah mendapatkan persetujuan etik (Ethical Approval) dengan nomor: Ref:005/KEPK/2016. 


\section{HASIL DAN PEMBAHASAN}

Penelitian dimulai dengan pengambilan data karakteristik pasien yang diperoleh dari lembar informasi dan ketersedian pasien menjadi responden dan data klinik dilihat dari rekam medik pasien. Populasi pasien hipertensi yang terdaftar di Puskesmas kecamatan Sumbang sebanyak 258 pasien. Responden yang memenuhi kriteria inklusi, eksklusi dan bersedia menjadi responden sebanyak 79 orang, yang mengikuti penelitian dari awal sampai akhir sebanyak 75 orang dan 4 orang drop out karena rekam medik pasien tersebut tidak dapat ditemukan. Sebanyak 25 orang sebagai kelompok intervensi dan 50 orang sebagai kelompok kontrol

Tabel I. Karakteristik umum pasien hipertensi berdasarkan umur, jenis kelamin, pekerjaan, dan jumlah jenis obat hipertensi.

\begin{tabular}{|c|c|c|c|}
\hline Karakteristik & $\begin{array}{c}\text { Intervensi } \mathbf{F}=\mathbf{2 5} \\
\text { n }(\%)\end{array}$ & $\begin{array}{c}\text { Kontrol } \mathbf{F}=\mathbf{5 0} \\
\text { n (\%) }\end{array}$ & $\mathbf{P}$ \\
\hline \multicolumn{4}{|l|}{ Umur } \\
\hline $0-50$ & $15(44,1)$ & $19(55,9)$ & $0,71 *$ \\
\hline$>50$ & $10(24,4)$ & $31(75,5)$ & \\
\hline \multicolumn{4}{|l|}{ Jenis kelamin } \\
\hline Laki-laki & $3(20,0)$ & $12(80,0)$ & $0,221 *$ \\
\hline Perempuan & $22(36,7)$ & $38(63,3)$ & \\
\hline \multicolumn{4}{|l|}{ Pekerjaan } \\
\hline Bekerja & $20(31,7)$ & $43(68,3)$ & $0,504 *$ \\
\hline Tidak bekerja & $5(41,7)$ & $7(58,3)$ & \\
\hline \multicolumn{4}{|l|}{ obat hipertensi } \\
\hline Tunggal & $11(34,4)$ & $21(65,6)$ & $0,868 *$ \\
\hline Kombinasi & $14(32,6)$ & $29(67,4)$ & \\
\hline
\end{tabular}

*Hasil analisis statistik dengan uji chi-square

Pembagian kelompok intervensi dan kontrol berdasarkan pertimbangan peneliti, dimana pasien yang mempunyai HP dimasukkan kedalam kelompok intervensi dan pasien yang tidak mempunyai HP sebagai kontrol. Pertimbangan ini terjadi karena populasi pasien hipertensi di Puskesmas kecamatan Sumbang yang mempunyai HP hanya 34 orang, sebanyak 5 orang tidak bersedia menjadi responden dan sebanyak 4 orang lupa tidak membawa HP dan lupa dengan nomor HP nya. Karakterisktik umum responden dalam penelitian ini adalah umur, jenis kelamin, pekerjaan, dan jumlah jenis obat hipertensi ditunjukan pada tabel I. Dari hasil uji statistik chi-square terhadap masing-masing variabel pada kelompok intervensi dan kontrol diperoleh nilai $\mathrm{p}>0,05$ yang menunjukan tidak terdapat 
perbedaan proporsi masing-masing variabel antara kelompok intervensi dan kontrol (tabel I). Responden pada kelompok intervensi dan kontrol didominasi oleh pasien perempuan hal ini sejalan dengan penelitian Putri (2012) dan hasil Riset kesehatan dasar 2007 menyatakan bahwa prevalensi hipertensi berdasarkan jenis kelamin didominasi oleh perempuan (Kemenkes, 2013). Responden berdasarkan umur didominasi umur $>50$ tahun, hal ini tidak sejalan dengan penelitian Putri (2012) yang menyatakan bahwa hipertensi didominasi oleh pasien berumur 35-64 tahun, dan tidak sejalan pula dengan penelitian Alfian (2014) yang menyatakan bahwa prevalensi pasien hipertensi > 50 tahun lebih sedikit dari pada 0-50 tahun. Responden berdasarkan pekerjaan didominasi oleh pasien yang bekerja dibandingkan tidak bekerja, hal ini tidak sejalan dengan penelitian Putri (2012) yang menyatakan bahwa prevalensi pasien hipertensi didominasi oleh pasien yang tidak bekerja. Responden didominasi dengan jumlah jenis obat hipertensi kombinasi, hal ini tidak sejalan dengan penelitian Putri (2012) yang menyatakan bahwa prevalensi hipertensi memperoleh obat jenis hipertensi tunggal lebih banyak dibandingkan kombinasi. Hipertensi merupakan penyakit degenerasi, umumnya tekanan darah meningkat secara perlahan dengan bertambahnya umur. Risiko untuk menderita hipertensi pada populasi $>55$ tahun, dan kebanyakan diagnosis hipertensi terjadi pada umur diantara dekade ketiga dan kelima sampai dengan umur 55 tahun laki-laki lebih banyak dibanding perempuan, sedangkan dari umur 55 sampai 74 tahun prevalensi perempuan sedikit lebih banyak dari pada laki-laki (DepKes, 2006). Laki-laki cenderung memliki gaya hidup yang dapat meningkatkan tekanan darah dibanding perempuan, namun setelah memasuki umur menopause perempuan akan kehilangan hormon estrogen yang meningkatkan HDL akibatnya apabila HDL menurun maka dapat menyebabkan arterosklerosis sehingga perempuan menopause akan lebih mudah terkena hipertensi (Jaya, 2009). Terapi untuk pasien hipertensi esensial adalah pengobatan anti hipertensi tunggal yaitu diuretik thiazida yang merupakan terapi pilihan utama, sehingga terapi pasien hipertensi dalam penelitian ini sesuai dengan terapi hipertensi esensial. 
Hasil uji normalitas terhadap karakteristik responden dengan menggunakan uji Kolmogorov-Smirnov karena responden >50 (Dahlan, 2012), menunjukan bahwa distribusi karakteristik responden penelitian pada kelompok perlakuan dan kontrol berdasarkan jenis kelamin, umur, pekerjaan, obat hipertensi diperoleh nilai $\mathrm{p}=0,000$ hal ini menunjukan bahwa distribusi tidak normal karena nilai $\mathrm{p}<0,05$

Penelitian ini menguji tentang pengaruh layanan pesan singkat pengingat terhadap kepatuhan dan efektivitas pengobatan pasien hipertensi di Puskesmas Kecamatan Sumbang. Responden yang diberikan layanan pesan singkat pengingat (kelompok intervensi) terhadap kepatuhan nilai signifikasinya dengan analisis bivariat uji chi-square didapatkan $\mathrm{p}=0,102$ menunjukan bahwa tidak terdapat hubungan bermakna antara pemberian layanan pesan singkat pengingat terhadap kepatuhan karena nilai p> 0,05 (tabel II). Hal ini tidak sejalan dengan penelitian sebelumnya yang mengatakan bahwa pemberian layanan pesan singkat pengingat mampu memberikan dampak positif terhadap kepatuhan pasien hipertensi, pemberian layanan pesan singkat sebagai pengingat bertujuan untuk mengingatkan pasien minum obat anti hipertensi agar tumbuh kesadaran patuh minum obat, kepatuhan yang timbul didasari oleh kesadaran dari dalam diri sendiri akan bertahan lebih lama (Alfian, 2014).

Tabel II. Hubungan antara layanan pesan singkat pengingat terhadap kepatuhan dan efektivitas pengobatan pasien hipertensi.

\begin{tabular}{|c|c|c|c|}
\hline \multirow[t]{2}{*}{ Variabel } & \multicolumn{2}{|c|}{ Kelompok } & \multirow[t]{2}{*}{$\mathbf{P} *$} \\
\hline & Intervensi n (\%) & Kontrol n (\%) & \\
\hline \multicolumn{4}{|l|}{ Kepatuhan } \\
\hline Patuh & $15(27,8)$ & $39(72,2)$ & 0,102 \\
\hline Tidak patuh & $10(47,6)$ & $11(52,4)$ & \\
\hline \multicolumn{4}{|c|}{ Efektivitas pengobatan } \\
\hline Efektiv & $11(26,8)$ & $30(73,2)$ & 0,899 \\
\hline Tidak efektiv & $14(28,6)$ & $10(71,4)$ & \\
\hline
\end{tabular}

\footnotetext{
*Uji chi-square
}

Hubungan antara pemberian layanan pesan singkat pengingat terhadap efektivitas pengobatan hipertensi menunjukan bahwa efektivitas pengobatan hipertensi tidak dipengaruhi oleh layanan pesan singkat, karena dilihat dari nilai $\mathrm{p}$ $=0,899$ atau $\mathrm{p}>0,05$ artinya tidak ada hubungan antara layanan pesan singkat 
pengingat terhadap efektivitas pengobatan hipertensi. Menurut penelitian Putri (2012) pemberian obat hipertesi secara teratur mampu menormalkan tekanan darah, dengan tekanan darah yang tetap normal maka pengobatan hipertensi akan efektif.

Pemberian layanan pesan singkat pengingat diharapkan dapat mempermudah dan mempercepat memberikan informasi dan motivasi pasien untuk minum obat, adanya pemberian layanan pesan singkat yang diberikan selama 1 minggu sekali mendapat respon baik dari responden (Lestari, 2015). Penelitian lain menyebutkan bahwa pemberian layanan pesan singkat selama 7 hari berturut-turut dapat mempengaruhi kepatuhan (Alfian, 2014), sedangkan pada penelitian ini pemberian layanan pesan singkat setiap 3 hari sekali selama 1 bulan tidak dapat mempengaruhi kepatuhan dan efektivitas pengobatan. Hal ini dapat terjadi karena kepatuhan dipengaruhi oleh beberapa faktor seperti faktor disposisi yaitu pengetahuan, sikap, kepercayaan, keyakinan, nilai-nilai dan sebaginya, dan faktor pendukung seperti lingkungan fisik, sarana kesehatan, sikap perilaku petugas kesehatan (Lestari, 2015).

Dalam melaksanakan penelitian ini terdapat keterbatasan-keterbatasan penelitian, yaitu: jumlah responden sebagai intervensi hanya 25 orang, sehingga tidak mampu mewakili populasi Puskesmas Kecamatan Sumbang. Peneliti tidak dapat mengendalikan variabel konfonding terhadap tingkat pendidikan sehingga memungkinkan dapat mempengaruhi hasil penelitian. Kelemahan metode MPR diantaranya tidak dapat mengetahui apakah pasien tersebut mengkonsumsi obatnya atau tidak, dan dalam perhitungan di beberapa kasus dapat meng "over estimasi" adherence sehingga beberapa tahun terakhir metode MPR ini sudah mulai ditinggalkan dan diganti dengan metode PDC (Proportion of Days Covered). Peneliti tidak mengetahui perbedaan pengetahuan responden tentang penyakit dan pengobatan hipertensi sehingga dapat mempengaruhi hasil. Adapula hal-hal yang membuat bias penelitian ini seperti aktivitas fisik dan asupan makanan yang tidak dapat dikontrol oleh peneliti sehingga dapat mempengaruhi hasil penelitian. 


\section{KESIMPULAN}

Pemberian layanan pesan singkat 3 hari sekali selama 1 bulan menyatakan tidak terdapat hubungan pemberian layanan pesan singkat pengingat dengan kepatuhan dengan $p$ value dari uji chi-square 0,102 (P>0,05) dan tidak terdapat hubungan pemberian layanan pesan singkat pengingat dengan efektivitas pengobatan dengan $p$ value uji chi-square $=0,899(\mathrm{P}>0,05)$.

\section{UCAPAN TERIMAKASIH}

Terimakasih kepada Dinkes Purwokerto, Puskesmas Kecamatan Sumbang Kabupaten Banyumas.

\section{DAFTAR PUSTAKA}

Departemen Kesehatan, 2006, Pharmaceutical Care Penyakit Hipertensi, Jakarta: Direktorat Jenderal Bina Kefarmasian dan Alat Kesehatan Republik Indonesia.

Kementerian Kesehatan Republik Indonesia, 2013, Laporan Hasil Riset Kesehatan Dasar (RISKESDAS). Jakarta: Badan penelitian dan pengembangan kesehatan kementrian Republik Indonesia.

Word Health Organization, 2013, A global brief on Hipertension. World Health day.

Alfian, R., 2014, Layanan pesan singkat pengingat untuk meningkatkan kepatuhan dan menurunkan tekanan darah pasien hipertensi di RSUD Dr. H. Moch Ansari Saleh Banjarmasin, Jurnal Media Farmasi vol.11 (2). Hal.189-196.

Dahlan, M.S., 2012, .Statistik Untuk Kedokteran dan Kesehatan Edisi ke-5. Jakarta: Salemba Medika.

Febiyanti, K., 2012, Pengaruh ceramah kesehatan terhadap kepatuhan dan tekanan darah pasien hipertensi di Puskesmas Kecamatan Beji Kota Depok, Tesis, Depok: Universitas Indonesia.

Jaya, NTA., 2009, Faktor-faktor yang berhubungan dengan tingkat kepatuhan pasien dalam minum obat anti hipertensi di puskesmas Pamulang kota 
Tanggerang Selatan, Skripsi, Jakarta: Universitas Islam Negeri syarif Hidayatullah.

Lestari, D. D., 2015, Pengaruh pendidikan kesehatan dan sms rimender terhadap kepatuhan ibu hamil dalam mengkonsumsi tablet besi di wilayah kerja Puskesmas Pisangan, Skripsi, Jakarta: Universitas Islam Negeri Syarif Hidayatullah.

Putri, R.A., 2012, Analisis efektivitas pemberian konseling dan pemasangan poster terhadap tingkat kepatuhan dan nilai tekanan daearh pasien hipertensi di Puskesmas Bakti Jaya kota Depok, Tesis, Jakarta: Universitas Indonesia.

Rina, M.W., Mustofa, Ika P., 2015, Pengaruh konseling apoteker komunitas terhadap pasien hipertensi, Jurnal Managemen dan Pelayanan Farmasi, volume 5 (1).

Robertson TA, Cooke CE., 2008, Effect of medication burden on persistent use of lipid lowering drugs among patients with hypertension, Journal Am J Manag Care, 14(11):710-16.

Suhadi, 2010, Evaluasi ketaatan penggunaan antihipertensi di Apotek X Yogyakarta Periode Tahun 2009 Berdasarkan parameter Medication Possession Ratio, Jurnal Ilmu Kefarmasian Indonesia, Vol. 9. (1) Hal.53-59. 